\title{
MULTIAKAD DALAM TRANSAKSI SYARIAH KONTEMPORER PADA LEMBAGA KEUANGAN SYARIAH DI INDONESIA
}

\author{
Hasanudin Maulana*
}

\begin{abstract}
Multiagreements in Contemporary Islamic Transactions on Indonesian Islamic Financial Institutions. The development of Islamic finance in Indonesia affects the development of Islamic finance products dynamically. The agreement in Islamic transactions underwent a variety of innovations from several existing agreements in $m u$ 'âmalah jurisprudence concept. One of them is the concept of multi-agreements in a transaction. Transactions with these multiagreement forms exist in almost Islamic products currently. This article also discusses various scholarly opinions with all variants of the concept multi-agreements.
\end{abstract}

Keywords: multiagreements, al-bay', transactions

\begin{abstract}
Abstrak: Multiakad dalam Transaksi Syariah Kontemporer pada Lembaga Keuangan Syariah di Indonesia. Seiring dengan perkembangan ekonomi syariah, khususnya di Indonesia, maka produk-produk ekonomi syariah pun berkembang secara dinamis. Akad-akad dalam transaksi syariah pun mengalami pelbagai inovasi dari beberapa akad yang ada dalam konsep fikih muamalah yang telah ada selama ini. Salah satu inovasi tersebut adalah lahirnya konsep multiakad dalam suatu transaksi. Transaksi dengan bentuk multiakad ini hampir ada dalam semua produk syariah saat ini. Artikel ini juga akan menyajikan beragam pendapat ulama dengan segala variannya tentang konsep multiakad tersebut.
\end{abstract}

Kata Kunci: multiakad, al-bay", transaksi

Naskah diterima: 27 Oktober 2010, direvisi: 2 Desember 2010, disetujui: 9 Desember 2010.

* Dewan Syariah Nasional Majelis Ulama Indonesia (DSN-MUI). Jl. Proklamasi No. 51 Menteng, Jakarta Pusat. E-mail: abumafaz@yahoo.co.id 


\section{Pendahuluan}

Pertumbuhan dan perkembangan pesat aktivitas dan Lembaga Keuangan Syariah (LKS) di Indonesia saat ini, seperti perbankan syariah, asuransi syariah, pembiayaan syariah, obligasi syariah (sukuk al-istitsmâr), dan lain sebagainya menuntut para praktisi, regulator, dan bahkan akademisi bidang keuangan syariah untuk senantiasa aktif dan kreatif dalam rangka memberikan respon terhadap perkembangan tersebut. Para praktisi dituntut melakukan penciptaan pelbagai produk, regulator membuat regulasi yang mengatur dan mengawasi produk yang ditawarkan dan laksanakan oleh praktisi, dan akademisi pun dituntut memberikan pencerahan dan tuntunan agar produk maupun regulasi benarbenar tidak menyimpang dari prinsip-prinsip syariah.

Dalam rangka memenuhi kebutuhan masyarakat dan mengembangkan industri atau bisnis praktisi telah melakukan pelbagai upaya untuk menciptakan produk-produk baru atau bahkan-dan ini yang paling banyak-melakukan adaptasi dan "syariatisasi" terhadap produk-produk lama (konvensional). Untuk yang terakhir ini, mengingat fungsinya masih relavan dan diperlukan, nama produk lama tetap dipertahankan, tentu saja dengan diberi label khusus untuk membedakannya dari produk konvensional, misalnya diberi kata "syariah" atau kini-untuk di lingkungan perbankan syariah sesuai dengan peraturan perundang-undangan yang berlaku-diberi label "iB". Sebagai contoh dapat dikemukakan antara lain kartu kredit syariah, asuransi syariah, obligasi syariah, FX iB, dan Islamic Swap.

Salah satu parameter untuk menilai suatu produk apakah telah memenuhi prinsip syariah atau tidak adalah dengan memperhatikan akad-akad dan pelbagai ketentuannya yang digunakan dalam produk tersebut. Produk-produk dalam kegiatan keuangan syariah, jika terhadapnya dilakukan al-takyîf al-fiqhî, beberapa atau bahkan sebagian terbesar ternyata mengandung beberapa akad. Sebagai contoh, dalam transaksi kartu kredit syariah terdapat akad ijârah, qardh, dan kafâlah; obligasi syariah mengandung sekurang-kurangnya akad mudhârabah (atau ijârah) dan wakâlah, serta terkadang disertai kafâlah atau wa'd; Islamic swap mengandung beberapa kali akad tawarruq, bay', wakâlah, sharf, dan terkadang atau selalu disertai wa'd. Dalam setiap transaksi, akad-akad tersebut dilakukan secara bersamaan atau setidak-tidaknya setiap akad yang terdapat dalam suatu produk tidak bisa ditinggalkan, karena kesemuanya merupakan satu kesatuan. Transaksi seperti itulah yang dalam tulisan ini diistilahkan dengan "multiakad" yang kini dalam peristilahan fikih muamalah kontemporer (fiqh al-mu'âmalah al-mâliyah al-mu'âshirah) disebut dengan al-'uqûd al-murakkabah.

Dengan banyaknya transaksi modern yang menggunakan multiakad seba- 
gaimana disinggung di atas, kini atau bahkan pada dasawarsa terakhir ini mulai ramai diperbincangkan para ahli fikih sekitar keabsahan dari multiakad. Sejumlah tulisan, mulai tulisan berbentuk artikel sampai dengan tulisan ilmiah serius seperti tesis dan disertasi, bermunculan. Penulis pun menulis disertasi dengan topik Konsep dan Dhawâbith Multiakad dalam Fatwa DSN-MUI.

Perbincangan dan perdebatan mengenai keabsahan multiakad ini muncul bukan tanpa sebab. Sejumlah Hadis Nabi-sekurang-kurangnya tiga buah Hadis-secara lahiriah (ma'na zhâhir)- menunjukkan larangan penggunaan multiakad. Misalnya, Hadis tentang larangan untuk melakukan bay dan salaf, larangan bay' atayn fî bay‘ ah, dan shafqatayn fî shafqah. Dengan adanya Hadis-Hadis tersebut kiranya sangat wajar jika timbul pertanyaan, apakah produk-produk keuangan syariah yang menggunakan multiakad dapat dipandang memenuhi prinsip syariah atau sebaliknya.

Tulisan sederhana ini tidak dimaksudkan untuk menganalisis secara lengkap dan tafshîl terhadap produk-produk dimaksud, melainkan hanya sekadar akan membincang apa dan bagaimana sebenarnya konsep multiakad, multiakad seperti apa yang memenuhi prinsip syariah, dan tentu saja apa yang dimaksudkan oleh Nabi dengan Hadis-hadisnya tersebut, sebagai bahan diskusi.

\section{Model Multiakad}

Multi dalam bahasa Indonesia berarti: banyak, lebih dari satu, lebih dari dua, berlipat ganda. ${ }^{1}$ Dengan demikian, multiakad dalam bahasa Indonesia berarti akad berganda atau akad yang banyak, lebih dari satu.

Sedangkan menurut istilah fikih, kata multiakad merupakan terjemahan dari kata Arab yaitu al-'uqûd al-murakkabah yang berarti akad ganda (rangkap). Al-'uqûd al-murakkabah terdiri atas dua kata al-'uqûd (bentuk jamak dari 'aqd) dan al-murakkabah. Kata al-murakkabah (murakkab) secara etimologi berarti aljam'u, yakni mengumpulkan atau menghimpun. ${ }^{2}$ Kata murakkab sendiri berasal dari kata rakkaba-yurakkibu-tarkîban yang mengandung arti meletakkan sesuatu pada sesuatu yang lain sehingga menumpuk, ada yang di atas dan yang di bawah. ${ }^{3}$ Sedangkan murakkab menurut pengertian para ulama fikih adalah: Pertama, himpunan beberapa hal sehingga disebut dengan satu nama. Seseorang menjadikan beberapa hal menjadi satu hal (satu nama) dikatakan sebagai

${ }^{1}$ Tim Penyusun, Kamus Besar Bahasa Indonesia, (Jakarta: Balai Pustaka, 1996), Edisi II, h. 671.

${ }^{2}$ Kata al-jam' menunjukkan berkumpulnya sesuatu (tadhâmm al-syay'). Al-Tahânawî, Kasysyâf Ishthilâhât al-Funûn, (Bayrût: Dâr Shâdir, tt.), Jilid II, h. 534.

${ }^{3}$ Al-Jawharî, Al-Shihâh, Jilid I, h. 139. Al-Fairûz al-Abâdî, Al-Qâmûs al-Muhîth, h.117. 
melakukan penggabungan (tarkîb). Kedua, sesuatu yang dibuat dari dua atau beberapa bagian, sebagai kebalikan dari sesuatu yang sederhana (tunggal/ basith) yang tidak memiliki bagian-bagian. Ketiga, meletakkan sesuatu di atas sesuatu lain atau menggabungkan sesuatu dengan yang lainnya. ${ }^{4}$

Ketiga pengertian ini memiliki kelebihan dan kekurangan masing-masing untuk menjelaskan makna persis dari istilah murakkab. Pengertian pertama lebih tepat untuk digunakan karena mengandung dua hal sekaligus, yaitu terhimpunnya beberapa hal dan bersatunya beberapa hal itu yang kemudian menjadi satu pengertian tertentu.

Pengertian kedua tidak menjelaskan akibat dari terhimpunnya beberapa hal itu. Walaupun pengertian kedua menyatakan adanya gabungan dua atau beberapa hal, tetapi tidak menjelaskan apa dan bagaimana setelah terjadi penggabungan tersebut. Pengertian terakhir lebih dekat kepada pengertian etimologis, tidak menjelaskan pengertian untuk suatu istilah tertentu.

Dengan demikian pengertian pertama lebih dekat dan pas untuk menjelaskan maksud al-'uqûd al-murakkabah dalam konteks fikih muamalah. Karena itu, akad murakkab menurut Nazih Hammad adalah:



Kesepakatan dua pihak untuk melaksanakan suatu akad yang mengandung dua akad atau lebih, seperti jual beli dengan sewa menyewa, hibah, wakâlah, qardh, muzâra'ah, sharaf (penukaran mata uang), syirkah, mudhârabah, dst., sehingga semua akibat hukum akad-akad yang terhimpun tersebut, serta semua hak dan kewajiban yang ditimbulkannya dipandang seba-

4 'Abd Allâh Ibn Muhammad bin 'Abd Allâh al-'Imrânî, Al-'uqûd al-Mâliyah al-Murakkabah: Dirâsah Fiqhiyyah Ta’shîliyyah wa Tathbîqiyyah, (Riyâdh: Dâr Kunûz Eshbelia li al-Nasyr wa al-Tauzî', 2006), Cet. I, h. 45.

${ }^{5}$ Nazîh Hammâd, Al-'Uqûd al-Murakkabah fî al-Fiqh al-Islâmî, (Damaskus: Dâr al-Qalam, 2005), Cet. I, h. 7. 
gai satu kesatuan yang tidak dapat dipisah-pisahkan, sebagaimana akibat hukum dari satu akad.

Sedangkan menurut al-'Imrânî, akad murakkab adalah:



Himpunan beberapa akad kebendaan yang dikandung oleh sebuah akad, baik secara gabungan maupun secara timbal-balik, sehingga seluruh hak dan kewajiban yang ditimbulkannya dipandang sebagai akibat hukum dari satu akad.

Selain istilah akad murakkab, ada beberapa istilah lain yang digunakan ahli fikih yang memiliki hubungan, kemiripan, dan kesamaan dengan pengertian akad murakkab. Istilah-istilah itu antara lain al-'uqûd al-mujtami'ah, al-'uqûd almuta'addidah, al-'uqûd al-mutakarrirah, al-'uqûd al-mutadâkhilah, al-'uqûd almukhtalithah.

Berikut adalah penjelasan pengertian dari beberapa istilah yang mirip dengan murakkab ini. Pertama, al-ijtimâ'. Kata ini mengandung arti terhimpun atau terkumpul, lawan dari terpisah. Sesuatu yang terhimpun dari beberapa bagian meski tidak menjadi satu bagian adalah arti dari kata ijtimâ'. ${ }^{7}$ Dengan begitu al-'uqûd al-mujtami'ah berarti terhimpunnya dua akad atau lebih dalam satu akad.

Sekilas ada persamaan antara istilah murakkab dan mujtami‘ah, yaitu adanya unsur terhimpunnya beberapa akad dalam satu akad. Bedanya, dalam murakkab beberapa akad itu lebur menjadi satu akad (transaksi) yang memiliki implikasi dan satu akibat hukum. Sedangkan dalam mujtami'ah, belum tentu terjadi peleburan akad. Artinya, dalam ijtimâ‘ beberapa akad itu dapat melebur menjadi satu akad dan dapat pula akad-akad tersebut berdiri sendiri-sendiri. Dalam kondisi pertama, akad mujtami'ah dapat disebut dengan-dan merupakan salah satu bentuk—akad murakkab, sedangkan dalam kondisi kedua (tidak

${ }^{6}$ 'Abd Allâh bin Muhammad bin 'Abd Allâh al-'Imrânî, Al-'Uqûd al-Mâliyah al-Murakkabah, h.46.

${ }^{7}$ Ibn Manzhûr, Lisân al-'Arab, Jilid VIII, h. 53. Lihat juga al-Fayruz Abâdi, Al-Qâmûs al-Muhîth, h. 917. 
melebur menjadi satu), ia tidak dapat dikategorikan akad murakkab. Contoh akad mujtami'ah adalah akad sewa-menyewa (ijârah) dan jual beli (bay') yang digabungkan menjadi satu meskipun kedua akad tetap eksis.

Dengan demikian, pengertian ijtimâ‘ (mujtami'ah) lebih luas dari pada murakkab, karena ijtimâ' mencakup murakkab dan tidak murakkab. Ulama pun tidak sekata atas penggunaan istilah ijtimâ' ini. Al-'Imrânî tampaknya membedakan istilah murakkab dan mujtami'ah seperti diuraikan di atas. ${ }^{8}$ Akan tetapi Nazih terlihat mempersamakan istilah murakkab dan mujtami'ah. Dalam beberapa pembahasan, Nazih mencampuradukkan antara istilah akad murakkab dan akad mujtami'ah. ${ }^{9}$

Kedua, al-ta'addud. Kata ta'addud berarti berbilang dan bertambah. Ta'addud dalam terminologi akad adalah adanya tambahan jumlah syarat, akad, pela$\mathrm{ku}$, harga, objek, atau sejenisnya. ${ }^{10}$ Istilah ta'addud lebih umum dari pada murakkab. Akad murakkab yang diartikan sebagai terhimpunnya dua akad atau lebih dalam satu akad, adalah makna dari terbilang (ta'addud) dalam akad. Bedanya, ta'addud mengandung persoalan-persoalan yang tidak termasuk dalam tujuan akad murakkab, seperti berbilangnya dua pihak, atau dalam harga, benda, atau lainnya. ${ }^{11}$ Karena itu ada perbedaan mendasar antara murakkab dan ta'addud, dimana murakkab mengandung konsekuensi satu, sedangkan ta'addud konsekuensinya bisa berbilang.

Ketiga, al-tikrâr. Al-tikrâr berarti berulang. Kata ini digunakan untuk menunjukkan adanya proses terhimpun atau terulangnya sesuatu. Sedangkan secara terminologi al-tikrâr diartikan sebagai mengulangi sesuatu yang telah dilakukan. Dalam hal akad, al-tikrâr berarti mengulangi akad yang telah dilakukan sebelumnya. ${ }^{12}$ Bedanya dengan murakkab dalam akad, kalau al-tikrâr meski berarti pula mengumpulkan tetapi maksud yang paling tetap untuk istilah ini adalah mengulangi akad yang sudah dilakukan dalam beberapa transaksi. Sedangkan dalam murakkab yang terjadi adalah terhimpunnya dua akad atau lebih menjadi satu akad atau transaksi.

Keempat, al-tadâkhul. Al-tadâkhul secara bahasa berarti masuk (al-wulûj), masuknya sesuatu pada sesuatu yang lain, keserupaan beberapa hal dan saling meliputi. Al-tadâkhul juga berarti masuknya suatu bagian pada bagian yang lain.

\footnotetext{
${ }^{8}$ Al-'Imrânî, Al-'Uqûd al-Mâliyah al-Murakkabah, h. 47-48.

${ }^{9}$ Nazih Hammâd, al-'Uqûd al-Murakkabah, h. 7 dst. Lihat juga Nazih Hammâd, Qadhâyâ Fiqhiyyah Mu'âshirah fi al-Mâl wa al-Iqtishâd, (Damaskus: Dâr al-Qalam, 2001), h. 249-273.

${ }^{10}$ Al-'Imrânî, Al-’uqûd al-Mâliyah al-Murakkabah, h. 49.

${ }^{11}$ Al-'Imrânî, Al-'uqûd al-Mâliyah al-Murakkabah, h. 49.

${ }^{12}$ Al-'Imrânî, Al-'uqûd al-Mâliyah al-Murakkabah, h. 50.
} 
Arti terakhir ini lebih spesifik karena yang masuk adalah suatu bagian pada bagian yang lainnya, sedangkan pengertian pertama lebih luas karena mencakup masuknya sesuatu pada sesuatu yang lain. Sesuatu itu dapat berupa bagian atau suatu yang utuh.

Dalam terminologi fikih, al-tadâkhul diartikan sebagai terhimpunnya suatu hal tertentu dalam dua ketentuan hukum agama (syar'i) dan cukup hanya melakukan salah satu ketentuan hukum tersebut pada umumnya boleh dipilih, namun akibat hukum keduanya atau salah satunya dapat tercapai. ${ }^{13}$ Dari pengertian ini, al-tadâkhul mengandung pula makna pengumpulan. Akan tetapi pengumpulan akad di sini dapat tercukupi dengan salah satu akadnya, tanpa akad yang lain. Sementara pada murakkab, kedua akad atau lebih tidak bisa dipisahkan satu dari yang lainnya. Keduanya digabungkan menjadi satu transaksi tersendiri yang berakibat hukum pada objek transaksi dengan akibat yang satu. Jadi jelas, perbedaan mendasarnya bahwa murakkab meniscayakan leburnya dua atau lebih akad menjadi satu yang memiliki akibat hukum yang satu pula (dalam arti tidak bisa dipisahkan), namun akad-akad tersebut harus dilaksanakan.

Kelima, al-ikhtilâth. Kata ini memiliki makna yang sama dengan al-jam'u. Al-Ikhtilâth berarti terhimpun, terkumpul, insert (tadâkhul), dan melebur. Seperti contoh seseorang mencampurkan sesuatu pada yang lain, maka keduanya tercampur atau terkumpul. Tercampurnya dua hal itu bisa berakibat melebur menjadi satu sehingga kedua hal itu tidak bisa dibedakan seperti tercampurnya barang-barang cair, dan bisa juga dibedakan seperti dikumpulkannya suatu hewan dengan hewan yang lain.

Multiakad ('uqûd mukhtalithah) mengandung arti seperti akad murakkab, yaitu akad-akad yang terhimpun dalam satu akad yang menimbulkan akibat hukum satu akad. ${ }^{14}$

'Uqûd mukhtalithah (contract mixed) adalah menghimpun beberapa akad modern di mana satu akad melebur dengan akad lainnya. Dengan kata lain akad yang terdiri atas peleburan beberapa akad yang berbeda menjadi satu akad. ${ }^{15}$ Contoh akad yang mukhtalith adalah mengontrak rumah. Beberapa akad yang ada di dalamnya adalah akad sewa untuk ruangan tinggal, akad bekerja sebagai pembantu, akad jual beli berkenaan dengan makanannya, dan akad wadî'ah berkenaan dengan penitipan barang-barang (amti'ah).

\footnotetext{
${ }^{13}$ Al-'Imrânî, Al-’uqûd al-Mâliyah al-Murakkabah, h. 51.

${ }^{14}$ Al-'Imrânî, Al-'uqûd al-Mâliyah al-Murakkabah, h. 52.

${ }^{15}$ Ramadhân Muhammad Abû al-Sa'ûd, Mabâdi al-Iltizâm fî al-Qânûn al-Mishri wa al-Banânia,
} h.42. 
Akad mukhtalith digunakan pula untuk menyebutkan akad murakkab. Keduanya memiliki makna yang sama, hanya berbeda dari sisi kedalaman maknanya saja. Kata murakkab lebih spesifik dan khusus untuk multiakad ketimbang mukhtalith yang dapat pula mengandung arti yang lain. ${ }^{16}$ Baik akad murakkab maupun mukhtalith dimaksudkan untuk menyatakan terhimpunnya beberapa akad menjadi satu akad dan berimplikasi hukum satu pada objek akadnya.

Al-'Imrânî membagi multiakad dalam lima macam, yaitu: al-'uqûd almutaqâbilah, al-'uqûd al-mujtami'ah, al-'uqûd al-mutanâqidhah wa al-mutadhâdah wa al-mutanâfiyah, al-'uqûd al-mukhtalifah, al-'uqûd al-mutajânisah. Dari lima macam itu, menurut dia, dua macam yang pertama yaitu al-'uqûd almutaqâbilah dan al-'uqûd al-mujtami'ah, adalah multiakad yang umum dipakai. Berikut penjelasan dari lima macam multiakad tersebut.

Pertama, akad bergantung/akad bersyarat (al-'uqûd al-mutaqâbilah). Taqâbul menurut bahasa berarti berhadapan. Sesuatu dikatakan berhadapan jika keduanya saling menghadapkan kepada yang lain. Sedangkan yang dimaksud dengan al-'uqûd al-mutaqâbilah adalah multiakad dalam bentuk akad kedua merespon akad pertama, ${ }^{17}$ di mana kesempurnaan akad pertama bergantung pada sempurnanya akad kedua melalui proses timbal balik. Dengan kata lain, akad satu bergantung dengan akad lainnya.

Dalam tradisi fikih, model akad seperti ini sudah dikenal lama dan praktiknya sudah banyak. Banyak ulama telah membahas tema ini, baik yang berkaitan dengan hukumnya, atau model pertukarannya. Misalnya antara akad pertukaran (mu'âwadhah) dengan akad tabarru', antara akad tabarru' dengan akad tabarru' atau akad pertukaran dengan akad pertukaran. Ulama biasa mendefinisikan model akad ini dengan akad bersyarat (isytirâth 'aqd bi 'aqd). ${ }^{18}$

Kedua, akad terkumpul (al-'uqûd al-mujtami‘ah). Al-'uqûd al-mujtami'ah adalah multiakad yang terhimpun dalam satu akad. Dua atau lebih akad terhimpun menjadi satu akad. Seperti contoh, "Saya jual rumah ini kepadamu dan saya sewakan rumah yang lain kepadamu selama satu bulan dengan harga lima ratus ribu".

Multiakad yang mujtami‘ah ini dapat terjadi dengan terhimpunnya dua akad yang memiliki akibat hukum berbeda di dalam satu akad terhadap dua objek dengan satu harga, dua akad berbeda akibat hukum dalam satu akad terhadap dua objek dengan dua harga, atau dua akad dalam satu akad yang

${ }^{16}$ Al-'Imrânî, Al-’uqûd al-Mâliyah al-Murakkabah, h.53.

${ }^{17}$ Imâm Mâlik ibn Anas, Al-Mudawwanah al-Kubrâ, j. 4, (Bayrût: Dâr al-Shâdir, 1323 H), cet. ke-1, h.126.

${ }^{18}$ Al-'Imrânî, Al-’uqûd al-Mâliyah al-Murakkabah, h.57. 
berbeda hukum atas satu objek dengan satu imbalan, baik dalam waktu yang sama atau waktu yang berbeda.

Ketiga, akad berlawanan (al-'uqûd al-mutanâqidhah wa al-mutadhâdah wa al-mutanâfiyah). Ketiga istilah ini, al-mutanâqidhah, al-mutadhâdah, almutanâfiyah, memiliki kesamaan bahwa ketiganya mengandung maksud adanya perbedaan. Tetapi ketiga istilah ini mengandung implikasi yang berbeda.

Mutanâqidhah mengandung arti berlawanan, seperti pada contoh seseorang berkata sesuatu lalu berkata sesuatu lagi yang berlawanan dengan yang pertama. Seseorang mengatakan bahwa sesuatu benar, lalu berkata lagi sesuatu itu salah. Perkataan orang ini disebut mutanâqidhah, saling berlawanan. Dikatakan mutanâqidhah karena antara satu dengan yang lainnya tidak saling mendukung, melainkan mematahkan. ${ }^{19}$

Keempat, akad berbeda (al-'uqûd al-mukhtalifah). Yang dimaksud dengan multiakad yang mukhtalifah adalah terhimpunnya dua akad atau lebih yang memiliki perbedaan semua akibat hukum diantara kedua akad itu atau sebagiannya. Seperti perbedaan akibat hukum dalam akad jual beli dan sewa. Dalam akad sewa diharuskan ada ketentuan waktu, sedangkan dalam jual beli sebaliknya. Contoh lain, akad ijârah dan salam. Dalam salam, harga salam harus diserahkan pada saat akad (fî al-majlis), sedangkan dalam ijârah, harga sewa tidak harus diserahkan pada saat akad.

Perbedaan antara multiakad yang mukhtalifah dengan yang mutanâqidhah, mutadhâdah, dan mutanâfiyah terletak pada keberadaan akad masingmasing. Meskipun kata mukhtalifah lebih umum dan dapat meliputi ketiga jenis yang lainnya, namun dalam mukhtalifah meskipun berbeda tetap dapat ditemukan menurut syariat. Sedangkan untuk kategori berbeda yang ketiga mengandung adanya saling meniadakan di antara akad-akad yang membangunnya. ${ }^{20}$

Dalam kajian ini, yang dimaksud dengan mutanâqidhah adalah: Pertama, dua hal yang tidak dapat terhimpun secara bersama (pada saat yang sama) dan tidak pula dapat tiada pada saat yang sama, seperti hadirnya seseorang dan ketidakhadirannya. Jika seseorang hadir, maka tidak hadirnya tiada, tetapi jika tiada hadir yang ada, maka hadirnya tiada. ${ }^{21}$ Kedua, dua hal yang saling bertolak belakang dan berlawanan, yang mana kehadiran yang satu menuntut ketiadaan yang lainnya, begitu pula sebaliknya. Seperti contoh antara menyerahkan (îjâb)

\footnotetext{
${ }^{19}$ Ashfahânî, Mu'jam Mufradât alfâdz al-Qur'ân, h.525.

${ }^{20}$ Ashfahânî, Mu'jam Mufradât alfâdz al-Qur'ân, h.2157.

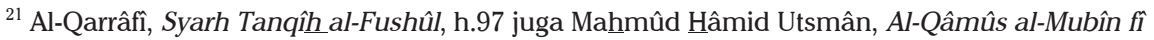
Ishthilâhât al-Ushûliyyîn, (Riyâdh: Dâr al-Zâhim, 1423 H), cet. ke-1, h. 292.
} 
dan menarik (salb). ${ }^{22}$ Ketiga, dua hal yang saling menafikan antara yang satu dengan lainnya. ${ }^{23}$

Sedangkan arti etimologi dari mutadhâdah adalah dua hal yang tidak mungkin terhimpun dalam satu waktu, seperti antara malam dan siang. Secara terminologis, mutadhâdah diartikan: Pertama, dua hal yang tidak dapat terhimpun pada saat yang sama, dan mungkin dapat hilang keduanya meskipun ada perbedaan dalam hakekatnya, seperti antara hitam dan putih. Kedua, dua sifat yang saling mengganti (muta'âqibân) pada satu objek, namun tidak mungkin disatukan, seperti hitam dan putih. Ketiga, saling menerima dan menafikan secara umum dan dalam kondisi tertentu, seperti hitam dan putih. Keempat, sesuatu yang tidak mungkin dipersatukan dalam satu objek.

Tampak jelas perbedaan antara mutanâqidhah dan mutadhâdah. Pada mutanâqidhah tidak mungkin dua hal bertemu dan keduanya tidak mungkin tiada pada saat yang sama, seperti pergi dan pulang. Sedangkan mutadhâdah dua hal tidak mungkin dipersatukan saling meniadakan seperti hitam dan putih, tetapi keduanya mungkin tiada pada saat yang sama. Sesuatu yang merah dapat menggantikan yang putih atau hitam. ${ }^{24}$

Adapun arti dari mutanâfiyah adalah menafikan, lawan dari menetapkan. Mutanâfiyah diartikan sebagai: Pertama, mustahilnya penyatuan dua hal dalam satu waktu pada satu objek, seperti antara hitam dan putih, ada dan tiada. Kedua, satu tempat (objek) dengan berbeda keadaan, baik karena kondisi bertolak belakang seperti bergerak dan diam, atau kondisi berlawanan seperti berdiri dan duduk. Ketiga, mustahilnya kemungkinan bertemunya dua hal yang bertolak belakang dalam satu tempat, satu waktu, satu abjek. Seperti mustahilnya ada dan tiada bersatu pada satu objek, satu waktu, dan satu tempat.

Dari pengertian di atas, para ahli fikih merumuskan maksud dari multiakad ('uqûd murakkabah) yang mutanâqidhah, mutadhâdah, dan mutanâfiyah, yaitu: Pertama, satu hal dengan satu nama tidak cocok untuk dua hal yang berlawanan, maka setiap dua akad yang berlawanan tidak mungkin dipersatukan dalam satu akad. Kedua, satu hal dengan satu nama tidak cocok untuk dua hal yang berlawanan, karena dua sebab yang saling menafikan akan menimbulkan akibat yang saling menafikan pula. Ketiga, dua akad yang secara praktik berlawanan dan secara akibat hukum bertolak belakang tidak boleh dihimpun. Keempat, haram terhimpunnya akad jual beli dan sharf dalam satu akad.

${ }^{22}$ Al-Jurjânî, al-Ta'rîfât, h.93 juga Al-Kafawî, al-Kulliyât, h.305.

${ }^{23}$ Ibn Qudâmah, Raudhah al-Nâdzir, J. 1, h.114.

${ }^{24}$ Mahmûu Hâmid Utsmân, Al-Qâmûs al-Mubîn fî Ishthilâhât al-Ushûliyyîn, h.197 juga AlJurjânî, al-Ta'rîfât, h.179. 
Mayoritas ulama Mâlikî berpendapat akadnya batal karena alasan ketentuan hukum kedua akad itu saling menafikan, yaitu bolehnya penundaan dan khiyâr dalam jual beli, sedangkan dalam sharf, penundaan dan khiyâr tidak diperbolehkan.

Ada dua pendapat mengenai terhimpunnya jual beli dan ijârah dan jual beli dengan sharf dengan satu imbalan ('iwadh). Pertama mengatakan kedua akad batal karena hukum dua akad berlawanan dan tidak ada prioritas satu akad atas yang lain karenanya kedua akad itu tidak sah. Pendapat kedua mengatakan, sah kedua akad dan imbalan dibagi untuk dua akad sesuai dengan harga masing-masing objek akad. Penggabungan ini tidak membatalkan akad.

Terhimpunnya dua akad atas objek yang memiliki harga berbeda dengan satu imbalan ('iwadh), seperti sharf dan bay' atau menjual barang yang dinyatakan bahwa akad telah mengikat sebelum serah terima, hukumnya sah, karena keduanya dapat dimintakan imbalan sebagai harga masing-masing. Oleh karena itu, kedua akad tersebut boleh dimintakan imbalan secara bersamaan. Menurut pendapat yang lain tidak sah, karena ketentuan hukumnya berbeda.

Dari pendapat ulama di atas disimpulkan bahwa multiakad yang mutanâqidhah, mutadhâdah, dan mutanâfiyah adalah akad-akad yang tidak boleh dihimpun menjadi satu akad. Meski demikian pandangan ulama terhadap tiga bentuk multiakad tersebut tidak seragam. ${ }^{25}$

Kelima, akad sejenis (al-'uqûd al-mutajânisah). Al-'uqûd al-murakkabah almutajânisah adalah akad-akad yang mungkin dihimpun dalam satu akad, dengan tidak mempengaruhi di dalam hukum dan akibat hukumnya. Multiakad jenis ini dapat terdiri atas satu jenis akad seperti akad jual beli dan akad jual beli, atau dari beberapa jenis seperti akad jual beli dan sewa menyewa. Multiakad jenis ini dapat pula terbentuk dari dua akad yang memiliki hukum yang sama atau berbeda.

\section{Status Hukum Multiakad}

Status hukum multiakad belum tentu sama dengan status hukum dari akad-akad yang membangunnya. Seperti contoh akad bay' dan salaf yang secara jelas dinyatakan keharamannya oleh Nabi. Akan tetapi jika kedua akad itu berdiri sendiri-sendiri, maka baik akad bay' maupun salaf diperbolehkan. Begitu juga dengan menikahi dua wanita yang bersaudara sekaligus haram hukumnya, tetapi jika dinikahi satu-satu (tidak dimadu) hukumnya boleh. Artinya, hukum multiakad tidak bisa semata dilihat dari hukum akad-akad yang membangunnya. Bisa jadi akad-akad yang membangunnya adalah boleh ketika berdiri sendiri, namun

\footnotetext{
${ }^{25}$ Al-'Imrânî, Al-'uqûd al-Mâliyah al-Murakkabah, h. 64.
} 
menjadi haram ketika akad-akad itu terhimpun dalam satu transaksi. Ketentuan seperti ini pernah diutarakan oleh al-Syâtibî, menurutnya:

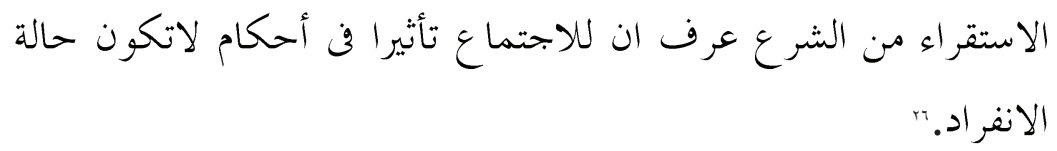

Penelitian terhadap hukum Islam menunjukkan bahwa dampak hukum dari sesuatu kumpulan (akad) tidak sama seperti saat akad itu berdiri sendirisendiri.

Dapat disimpulkan bahwa hukum dari multiakad belum tentu sama dengan hukum dari akad-akad yang membangunnya. Dengan kata lain, hukum akad-akad yang membangun tidak secara otomatis menjadi hukum dari multiakad.

Meski ada multiakad yang diharamkan, namun prinsip dari multiakad ini adalah boleh dan hukum dari multiakad dianalogikan dengan hukum akad yang membangunnya (قياس المجموع على احاده). Artinya setiap muamalah yang menghimpun beberapa akad, hukumnya halal selama akad-akad yang membangunnya adalah boleh. Ketentuan ini memberi peluang pada pembuatan model transaksi yang mengandung multiakad. Ketentuan ini berlaku umum, sedangkan beberapa Hadis Nabi dan nas-nas lain yang mengharamkan multiakad adalah ketentuan pengecualian. Hukum pengecualian ini tidak bisa diterapkan dalam segala praktik muamalah yang mengandung multiakad. ${ }^{27}$

Mengenai status hukum multiakad, ulama berbeda pendapat terutama berkaitan dengan hukum asalnya. Perbedaan ini menyangkut apakah multiakad sah dan diperbolehkan atau batal dan dilarang untuk dipraktikkan. Mengenai hal ini ulama berada dalam dua pendapat tersebut, yaitu membolehkan dan melarang.

Mayoritas ulama Hanafiyyah, sebagian pendapat ulama Mâlikiyyah, ulama Syâfi'iyyah, dan Hanâbilah berpendapat bahwa hukum multiakad sah dan diperbolehkan menurut syariat Islam. Bagi yang membolehkan beralasan bahwa hukum asal dari akad adalah boleh dan sah, tidak diharamkan dan dibatalkan selama tidak ada dalil hukum yang mengharamkan atau membatalkannya. ${ }^{28}$

\footnotetext{
${ }^{26}$ Al-Syâthibî, Al-Muwâfaqât, Jilid III, h.144-146.

${ }^{27}$ Nazîh Hammâd, al-'Uqûd al-Murakkabah, h.11-12.

${ }^{28}$ Al-'Imrânî, Al-'uqûd al-Mâliyah al-Murakkabah, h. 69.
} 
Menurut Ibn Taymiyyah, hukum asal dari segala muamalah di dunia adalah boleh kecuali yang diharamkan Allah dan Rasul-Nya, tiada yang haram kecuali yang diharamkan Allah, dan tidak ada agama kecuali yang disyariatkan. ${ }^{29}$

Hukum asal dari syariat adalah bolehnya melakukan transaksi multiakad, selama setiap akad yang membangunnya ketika dilakukan sendiri-sendiri hukumnya boleh dan tidak ada dalil yang melarangnya. Ketika ada dalil yang melarang, maka dalil itu tidak diberlakukan secara umum, tetapi mengecualikan pada kasus yang diharamkan menurut dalil itu. Karena itu, kasus itu dikatakan sebagai pengecualian atas kaidah umum yang berlaku yaitu mengenai kebebasan melakukan akad dan menjalankan perjanjian yang telah disepakati. ${ }^{30}$

Demikian pula dengan Ibn al-Qayyim. Dia berpendapat bahwa hukum asal dari akad dan syarat adalah sah, kecuali yang dibatalkan atau dilarang oleh agama. ${ }^{31}$ Karena hukum asalnya adalah boleh, maka setiap akad dan syarat yang belum dijelaskan keharamannya oleh Allah tidak bisa dinyatakan sebagai haram. Allah telah menjelaskan yang haram secara rinci, karenanya setiap akad yang dinyatakan haram harus jelas keharamannya seperti apa dan bagaimana. Tidaklah boleh mengharamkan yang telah dihalalkan oleh Allah atau dimaafkan, begitu pula tidak boleh menghalalkan yang telah diharamkan oleh-Nya. ${ }^{32}$

Al-Syâthibî menjelaskan perbedaan antara hukum asal dari ibadah dan muamalah. Menurutnya, hukum asal dari ibadah adalah melaksanakan (ta'abbud) apa yang diperintahkan dan tidak melakukan penafsiran hukum. Sedangkan hukum asal dari muamalah adalah mendasarkan substansinya bukan terletak pada praktiknya (iltifât ilâ ma'ânî). Dalam hal ibadah tidak bisa dilakukan penemuan atau perubahan atas apa yang telah ditentukan, sementara dalam bidang muamalah terbuka lebar kesempatan untuk melakukan perubahan dan penemuan yang baru, karena prinsip dasarnya adalah diperbolehkan (al-idzn) bukan melaksanakan ( $t a$ 'abbud). ${ }^{33}$

Pendapat ini didasarkan pada beberapa nas yang menunjukkan kebolehan multiakad dan akad secara umum. Pertama firman Allah dalam Q.s. al-Mâ'idah [5]: 1:

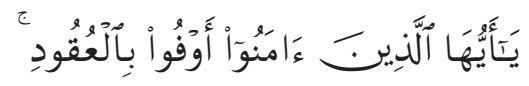

\footnotetext{
${ }^{29}$ Ibn Taymiyyah, Jâmi' al-Rasâ'il, Jilid II, h. 317.

${ }^{30}$ Nazîh Hammâd, al-'Uqûd al-Murakkabah fi al-Fiqh al-Islâmî, h. 8.

${ }^{31}$ Ibn al-Qayyim, I'lâm al-Muwaqqi'în, Jilid I, h. 344.

32 Ibn al-Qayyim, I'lâm al-Muwaqqi'în, Jilid I, h. 383.

${ }^{33}$ Al-Syâthibî, al-Muwâfaqât, Jilid I, h. 284.
} 
Wahai orang-orang yang beriman penuhilah olehmu akad-akad. (Q.s. alMâ'idah [5]: 1)

Akhir kalimat di atas adalah akad-akad ('uqûd). Dalam ayat ini Allah memerintahkan agar orang yang beriman memenuhi akad antar mereka. Kata akad ini disebutkan secara umum, tidak menunjuk pada akad tertentu. Artinya, secara prinsip semua akad diperbolehkan oleh Allah dan orang mukmin wajib memenuhi akad itu. Karena itu, al-Jashâsh menafsirkan ayat ini bahwa orang mukmin dituntut memenuhi akad-akad, termasuk akad jual-beli, sewa-menyewa, nikah, dan segala yang termasuk dalam kategori akad. Jika ada perbedaan mengenai boleh-tidaknya suatu akad, sah dan berlakunya suatu nadzar, ayat di atas dapat dijadikan dalil, karena keumuman ayat menunjukkan kebolehan segala bentuk akad, termasuk akad penjaminan (kafâlah), sewa menyewa, jual beli, dan sebagainya. $^{34}$

Nas lain yang menjadi dasar pendapat kelompok ulama ini adalah Q.s. alNisâ' [4]: 29 yang menyebutkan:

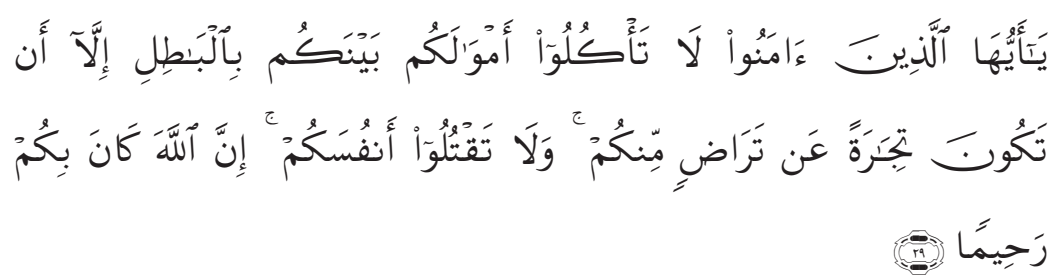

Hai orang-orang beriman janganlah kalian memakan harta-harta di antara kalian secara tidak benar kecuali atas dasar perniagaan dengan didasari saling rela di antara kalian. (Q.s. al-Nisâ' [4]: 29)

Ayat di atas menjelaskan bahwa dalam perniagaan hanya disyaratkan suka sama suka. Ini berarti bahwa suka sama suka adalah dasar kehalalan memperoleh sesuatu. Jika kerelaan menjadi dasar bagi kehalalan, maka setiap aktivitas yang didasari kerelaan menjadi halal berdasarkan petunjuk Alquran, selama tidak mengandung sesuatu yang diharamkan seperti perniagaan atas objek yang diharamkan, babi, khamr, barang najis dan sebagainya. Dari sini dapat disimpulkan bahwa hukum asal dari akad adalah boleh.

${ }^{34}$ Abû Bakar Ahmad al-Râzî al-Jashâsh, Ahkâm al-Qur'an, Jilid II, (Bayrût: Dâr al-Fikr, t.th.), Cet. I, h. 418. 
Ayat lain yang menjadi dasar pertimbangan pendapat kelompok yeng menyatakan hukum asal dari akad adalah boleh berupa firman Allah dalam Q.s. al-Baqarah [2]: 275 yang menjelaskan:

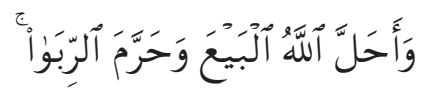

Allah menghalalkan jual-beli dan mengharamkan riba. (Q.s. al-Baqarah [2]: 275)

Jual beli yang dihalalkan Allah adalah segala bentuk jual beli, kecuali yang telah nyata diharamkan. Karena itu, kegiatan yang berkaitan dengan transaksi kebendaan pada dasarnya diperbolehkan.

Pendapat ini juga didukung oleh kaidah fiqhiyyah yang mengelompokkan akad, syarat, dan kegiatan keuangan lainnya sebagai kegiatan hubungan sosial. Dalam bidang ini berlaku kaidah umum al-ashl fî al-mu'âmalah al-ibâhah atau al'âdah muhakkamah. Berangkat dari sini, semua kegiatan sosial muamalah hukumnya boleh kecuali yang telah nyata jelas disebutkan keharamannya. ${ }^{35}$

Pertimbangan lain dari pendapat pertama ini adalah tidak ditemukannya keterangan yang mengharamkan semua jenis akad atau syarat dalam agama. Yang dijelaskan adalah secara umum tentang halalnya akad dan tidak dijelaskan keharamannya, kecuali atas objek tertentu. Karena tidak ada penjelasan yang menyatakan haram, maka akad hukumnya halal.

Ulama lain, terutama dari kalangan Zhâhiriyyah mengharamkan multiakad. Menurut kalangan Zhâhiriyyah hukum asal dari akad adalah dilarang dan batal kecuali yang ditunjukkan boleh oleh agama. Merekan beralasan bahwa Islam sudah sempurna, sudah dijelaskan apa yang diperlukan oleh manusia. Setiap perbuatan yang tidak disebutkan dalam nas-nas agama berarti membuat ketentuan sendiri yang tidak ada dasarnya dalam agama. Dan perbuatan seperti ini dianggap melampaui batas agama, seperti dinyatakan dalam surah al-Baqarah [2]: 229:

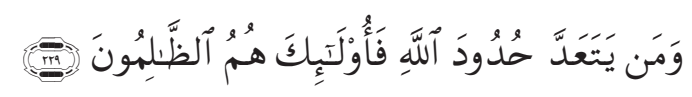

Barangsiapa yang melampaui ketentuan-ketentuan Allah, maka mereka itulah orang-orang yang zalim. (Q.s. al-Baqarah [2]: 229)

${ }^{35}$ Lihat Ibn Taymiyyah, Al-Qawâ'id al-Nûrâniyyah al-Fiqhiyyah, h. 222. 
Akad dan syarat yang tidak diajarkan oleh agama adalah bentuk tindakan melampaui ketentuan agama dan membuat hal baru dalam agama. Allah telah menyempurnakan turunnya Islam semasa Muhammad, seperti dijelaskan dalam Q.s. al-Mâidah (5): 3, "Pada hari ini telah Aku sempurnakan untukmu agamamu". Mendasarkan pada argumen di atas, kalangan Zhâhiriyyah menyimpulkan bahwa hukum asal dari akad adalah dilarang, kecuali yang dinyatakan kebolehannya oleh agama.

Dalil lain yang menguatkan pendapat Zhâhiriyyah ini adalah Hadis Nabi Muhammad yang mengatakan:

Dari Aisyah, Nabi bersabda, "Tiadalah sekelompok orang membuat syaratsyarat (perjanjian) yang tidak terdapat dalam Alquran. Setiap perjanjian yang tidak dinyatakan dalam Alquran hukumnya batal, meskipun seratus perjanjian. Ketentuan Allah lebih benar dan perjanjian-Nya lebih kuat. (H.r. al-Bukhârî)

Menurut Hadis ini, semua akad, syarat, dan janji dilarang selama tidak sesuai dengan apa yang telah dijelaskan dalam Alquran dan Hadis Nabi. Artinya, akad yang dibolehkan hanyalah akad yang telah dijelaskan dalam dua sumber hukum tersebut. ${ }^{36}$

Istidlâl dengan dalil-dalil yang dijadikan dasar oleh kalangan Zhâhiriyyah ini dapat dipatahkan dengan nas-nas lain dan relevansinya dengan kondisi perkembangan manusia terutama dalam bidang muamalah dan khususnya masalah kegiatan yang berkenaan dengan keuangan. Nas-nas yang disebutkan oleh pendapat pertama membuktikan bahwa agama tidak membatasi manusia secara sempit dalam urusan muamalahnya. Justru agama memberi peluang kepada manusia untuk melakukan inovasi dalam bidang muamalah agar memudahkan dalam kehidupan sehari-hari. Islam adalah agama yang memberi kemudahan bagi hambanya. Dan apa yang dijelaskan dalam nas dan Hadis yang melarang di atas, bukan berarti menutup segala akad sehingga hukumnya haram. Justru akad-akad yang tidak disebutkan dalam Alquran dan Hadis bukannya dilarang, melainkan bagi umat Islam diberi kesempatan untuk melakukan inovasi. Seperti dalam Hadis Nabi yang cukup dikenal, dimana Nabi menyerahkan urusan dunia kepada yang ahlinya dalam salah satu sabdanya, "Kalian lebih tahu dalam hal urusan dunia".

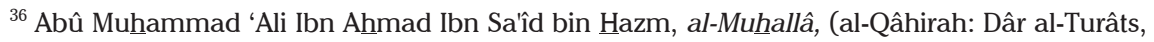
t.th.), Jilid V, h.15. 
Hadis ini memberi peluang kepada manusia untuk membuat akad yang bahkan baru sama sekali dan belum pernah dipraktikkan pada zaman Nabi, selama akad itu tidak melanggar prinsip-prinsip dasar dalam agama.

Dari sisi relevansi dengan kebutuhan zaman, pembaruan dan penemuan akad mutlak dibutuhkan. Perkembangan modern membuktikan bahwa banyak praktik muamalah dan transaksi keuangan yang belum pernah dipraktikkan pada masa Nabi dan tidak disebutkan secara jelas hukumnya dalam agama. Kebutuhan akad transaksi baru menjadi sebuah keniscayaan seiring dengan pertumbuhan manusia dan perkembangan ilmu dan teknologi.

Kalangan Mâlikiyyah dan Ibn Taymiyyah berpendapat bahwa multiakad merupakan jalan keluar dan kemudahan yang diperbolehkan dan disyariatkan selama mengandung manfaat dan tidak dilarang agama. Karena hukum asalnya adalah sahnya syarat untuk semua akad selama tidak bertentangan dengan agama dan bermanfaat bagi manusia. ${ }^{37}$

Dari paparan di atas, dapat diambil kesimpulan melalui metode muqâranah dan tarjîh bahwa pendapat pertama lebih kuat dan sesuai dengan perkembangan zaman dibanding dengan pendapat kedua. Kesimpulan ini didasarkan atas beberapa pertimbangan. Pertama, dalil yang digunakan pendapat pertama memiliki status yang kuat dan kejelasan makna yang dikandungnya. Kedua, kesesuaian dengan tujuan syariah (maqâshid syarî‘ah), yaitu adanya kemudahan dalam muamalah, keringanan dalam beban, dan memberi peluang inovasi. Ketiga, relevansi dengan perkembangan zaman dan kebutuhan manusia akan transaksi dan akad-akad modern. ${ }^{38}$

Kebolehan multiakad yang didasarkan atas prinsip hukum asal dari akad adalah boleh dan hukum multiakad di-qiyâs-kan dengan hukum akad-akad yang membangunnya, harus memperhatikan ketentuan-ketentuan agama yang membatasinya. Artinya, meskipun multiakad diperbolehkan, ada batasan-batasan yang tidak boleh dilanggar, karena batasan itu menjadi rambu bagi multiakad agar tidak terjerumus pada praktik muamalah yang diharamkan. Batasan-batasan sebagaimana dijelaskan pada bagian sebelumnya adalah garis batas bagi praktik multiakad yang tidak boleh dilewati.

\section{Batasan-batasan dan Standar Multiakad}

Para ulama yang membolehkan praktik multiakad bukan berarti membolehkan secara bebas, tetapi ada batasan-batasan yang tidak boleh dilewati. Karena batasan ini akan menyebabkan multiakad menjadi dilarang. Di kalangan

${ }^{37}$ Ibn Taymiyyah, Nazhariyat al-'Aqd, h. 227.

${ }^{38}$ Al-'Imrânî, Al-'uqûd al-Mâliyah al-Murakkabah, h. 74-75. 
ulama, batasan-batasan ini ada yang disepakati dan diperselisihkan. Secara umum, batasan yang disepakati oleh para ulama adalah, pertama, multiakad dilarang karena nas agama. Dalam Hadis, Nabi secara jelas menyatakan tiga bentuk multiakad yang dilarang, yaitu multiakad dalam jual beli ( bay $^{6}$ ) dan pinjaman (بيع وسلف), dua akad jual beli dalam satu akad jual beli ( بيعتين فى بيعة (واحدة), dan dua transaksi dalam satu transaksi (صفقتين فى صفقتين واحدة). Dalam sebuah Hadis disebutkan:



Dari Abu Hurairah, Rasulullah Saw. melarang jual beli dan pinjaman. (H.r. Ahmad)

Suatu akad dinyatakan boleh selama objek, harga, dan waktunya diketahui oleh kedua belah pihak. Jika salah satu di antaranya tidak jelas, maka hukum dari akad itu dilarang. Al-Syâfi'î memberi contoh, jika seseorang hendak membeli rumah dengan harga seratus, dengan syarat dia meminjamkan (salaf) kepadanya seratus, maka sebenarnya akad jual beli itu tidak jelas apakah dibayar dengan seratus atau lebih. Sehingga harga dari akad jual beli itu tidak jelas, karena seratus yang diterima adalah pinjaman ('âriyah). Sehingga penggunaan manfaat dari seratus tidak jelas, apakah dari jual beli atau pinjaman. ${ }^{40}$

Ibn Qayyim berpendapat bahwa Nabi melarang multiakad antara akad salaf (memberi pinjaman/qardh) dan jual beli, meskipun kedua akad itu jika berlaku sendiri-sendiri hukumnya boleh. Larangan menghimpun salaf dan jual beli dalam satu akad untuk menghindari terjerumus pada riba yang diharamkan. Hal itu terjadi karena seseorang meminjamkan (qardh) seribu, lalu menjual barang yang bernilai delapan ratus dengan harga seribu. Dia seolah memberi seribu dan barang seharga delapan ratus agar mendapatkan bayaran dua ribu. Di sini dia memperoleh kelebihan dua ratus. ${ }^{41}$

Selain multiakad antara salaf dan jual beli yang diharamkan, ulama juga sepakat melarang multiakad antara pelbagai jual beli dan qardh dalam satu

${ }^{39}$ Imâm Abû 'Abd Allâh Aḥmad Ibn Hanbal, Musnad Ahmmad, (Bayrû: Dâr al-Ihyâ al-Turâts al'Arabî, 1414 H), Jilid II, Cet. III, h.178.

${ }^{40}$ Al-Syâfi'î, Mukhtashar al-Muzanî, (Bahâmis al-Umm), Jilid II, h. 205.

${ }^{41}$ Ibn Qayyim al-Jawziyyah, I'lâm al-Muwaqqi'în 'an Rab al-'Alamîn, (al-Qâhirah: Maktabah Ibn Taymiyyah, t.th.), Jilid III, h. 153. 
transaksi. ${ }^{42}$ Semua akad yang mengandung unsur jual beli dilarang untuk dihimpun dengan qardh dalam satu transaksi, seperti antara ijarâh dan qardh, salam dan qardh, sharf dan qardh, dan sebagainya.

Meski penggabungan qardh dan jual beli ini dilarang, namun menurut al'Imrânî tidak selamanya dilarang. Penghimpunan dua akad ini diperbolehkan apabila tidak ada syarat di dalamnya dan tidak ada tujuan untuk melipatkan harga melalui qardh. Seperti seseorang yang memberikan pinjaman kepada orang lain, lalu beberapa waktu kemudian ia menjual sesuatu kepadanya padahal ia masih dalam rentang waktu qardh tersebut. Yang demikian hukumnya boleh. $^{43}$

Sedangkan larangan penghimpunan dua akad jual beli dalam satu akad jual beli didasarkan pada Hadis Nabi yang berbunyi:



Dari Abu Hurairah, berkata, "Rasulullah Saw. melarang dua jual beli dalam satu jual beli". (H.r. Mâlik)

Banyak pendapat dari para ulama mengenai maksud dari dua jual beli dalam satu jual beli. Pendapat yang dipilih (râjih ) dalam hal ini adalah pendapat yang mengatakan bahwa akad demikian menimbulkan ketidakjelasan harga dan menjerumuskan ke riba. Pendapat ini menafsirkan bahwa seseorang menjual sesuatu dengan dibayar secara cicil, dengan syarat pembeli harus menjual kembali kepada yang menjual dengan harga lebih rendah secara kontan. Akad seperti ini merupaka hîlah dari terjerumus pada riba, dan sebenarnya tidak terjadi akad jual beli dalam transaksi tersebut.

Jual beli seperti di atas dilarang manakala sebuah akad yang mengandung dua jual beli, salah satu dari jual beli itu dinyatakan sah dan mengikat (lâzim) sebelum para pihak berpisah namun tidak ditentukan jual beli manakah yang dinyatakan sah dan mengikat tersebut. 'Illat larangan bentuk jual beli ini adalah ketidakpastian (غرر) yang timbul dari ketidakjelasan (جهالة) nilai harga.

\footnotetext{
${ }^{42}$ Ibn Rusyd, Bidâyah al-Mujtahid, Jilid II, h. 162 juga Ibn Qudâmah, al-Mughnî, Jilid VI, h. 334.

${ }^{43}$ Al-'Imrânî, Al-'uqûd al-Mâliyah al-Murakkabah, h.180.

${ }^{44}$ Imâm Mâlik ibn Anas, Al-Muwaththa', Jilid II, h. 663.
} 
Kedua, multiakad sebagai hîlah ribawî. Multiakad yang menjadi hîlah ribawî dapat terjadi melalui kesepakatan jual beli 'înah atau sebaliknya dan hîlah riba fadhl.

Pertama, al-înah. Contoh 'înah yang dilarang adalah menjual sesuatu dengan harga seratus secara cicil dengan syarat pembeli harus menjualnya kembali kepada penjual dengan harga delapan puluh secara tunai. Pada transaksi ini seolah ada dua akad jual beli, padahal nyatanya merupakan hîlah riba dalam pinjaman ( qardh), karena objek akad semu dan tidak faktual dalam akad ini. Sehingga tujuan dan manfaat dari jual beli yang ditentukan syariat tidak ditemukan dalam transaksi ini.

Ibn al-Qayyim menjelaskan bahwa agama menetapkan seseorang yang memberikan qardh (pinjaman) agar tidak berharap dananya kembali kecuali sejumlah qardh yang diberikan, dan dilarang menetapkan tambahan atas qardh baik dengan hîlah atau lainnya. Demikian pula dengan jual beli disyariatkan bagi orang yang mengharapkan memberikan kepemilikan barang dan mendapatkan harganya, dan dilarang bagi yang bertujuan riba fadhl atau riba nasa', bukan bertujuan pada harga dan barang. ${ }^{45}$

Demikian pula dengan transaksi kebalikan 'înah juga diharamkan. Seperti seseorang menjual sesuatu dengan harga delapan puluh tunai dengan syarat ia membelinya kembali dengan harga seratus. Transaksi seperti ini telah menyebabkan adanya riba. ${ }^{46}$

Kedua, hîlah riba fadhl. Hal ini terjadi apabila seseorang menjual sejumlah harta ribawi, misalnya $2 \mathrm{~kg}$ beras, dengan sejumlah harga, misalnya Rp 10.000, dengan syarat bahwa ia-dengan harga yang sama (Rp 10.000)-harus membeli dari pembeli tadi sejumlah harta ribawi sejenis yang kadarnya lebih banyak (misalnya 3 kilogram) atau lebih sedikit (misalnya 1 kilogram). Transaksi seperti ini adalah model hîlah riba fadhl yang diharamkan. ${ }^{47}$

Transaksi seperti ini dilarang didasarkan atas peristiwa pada zaman Nabi Saw. dimana para penduduk Khaybar melakukan transaksi kurma kualitas sempurna satu kilo dengan kurma kualitas rendah dua kilo, dua kilo dengan tiga kilo dan seterusnya. Praktik seperti ini dilarang Nabi, dan beliau mengatakan agar ketika menjual kurma kualitas rendah dibayar dengan harga sendiri, begitu pula ketika membeli kurma kualitas sempurna juga dengan harga sendiri. ${ }^{48}$

\footnotetext{
${ }^{45}$ Ibn al-Qayyim, I'lâm al-Muwaqqi'în, Jilid III, h. 250.

${ }^{46}$ Ibn Qudâmah, Al-Mughnî, Jilid VI, h. 263 juga Mansur Ibn Yûnus Ibn Idrîs al-Bahuti, Kasyâf al-Qanâ' 'an Matn al-Iqnâ', (Bayrût: Dâr al-Fikr, 1402 H), Jilid III, h. 174.

${ }^{47}$ Ibn Qudâmah, Al-Mughnî, Jilid VI, h.114.

${ }^{48}$ Imâm Muslim, Shahîh $\underline{h}$ Muslim, Jilid III, h. 1208, juga Imâm al-Bukhârî, Shahîh al-Bukhârî,
} 
Maksud Hadis di atas, menurut Ibn al-Qayyim, adalah akad jual beli pertama dengan kedua harus dipisah. Jual beli kedua bukanlah menjadi syarat sempurnanya jual beli pertama, melainkan berdiri sendiri. Hadis di atas ditujukan agar dua akad itu dipisah, tidak saling berhubungan, apalagi saling bergantung satu dengan lainnya. ${ }^{49}$

Ketiga, multiakad menyebabkan jatuh ke riba. Setiap multiakad yang mengantarkan pada yang haram, seperti riba, hukumnya haram, meskipun akadakad yang membangunnya adalah boleh. Penghimpunan beberapa akad yang hukum asalnya boleh namun membawanya pada yang dilarang menyebabkan hukumnya menjadi dilarang. Hal ini terjadi seperti pada contoh: Pertama, multiakad antara akad salaf dan jual beli. Seperti dijelaskan sebelumnya, bahwa Nabi melarang multiakad antara akad jual dan salaf. Larangan ini disebabkan karena upaya mencegah (dzarî̀ah) jatuh pada yang diharamkan berupa transaksi ribawi. Jumhur ulama melarang praktik multiakad ini, yakni terjadinya penghimpunan akad jual beli (mu'âwadhah) dengan pinjaman ( $q a r d h$ ) apabila dipersyaratkan. Jika transaksi multiakad ini terjadi secara tidak disengaja diperbolehkan karena tidak adanya rencana untuk melakukan qardh yang mengandung riba. ${ }^{50}$

Kedua, multiakad antara qardh dan hibah kepada pemberi pinjaman (muqridh). Ulama sepakat mengharamkan qardh yang dibarengi dengan persyaratan imbalan lebih, berupa hibah atau lainnya. Seperti contoh, seseorang meminjamkan (memberikan utang) suatu harta kepada orang lain, dengan syarat ia menempati rumah penerima pinjaman (muqtaridh), atau muqtaridh memberi hadiah kepada pemberi pinjaman, atau memberi tambahan kuantitas atau kualitas objek qardh saat mengembalikan. Transaksi seperti ini dilarang karena mengandung unsur riba. Apabila transaksi pinjam-meminjam ini kemudian disertai hadiah atau kelebihan, tetapi dilakukan sendiri secara sukarela oleh orang yang diberi pinjaman, tanpa ada syarat dan kesepakatan sebelumnya hukumnya halal, karena tidak mengandung unsur riba di dalamnya. ${ }^{51}$

Keempat, multiakad terdiri atas akad-akad yang akibat hukumnya saling bertolak belakang atau berlawanan. Kalangan ulama Mâlikiyyah mengharamkan multiakad antara akad-akad yang berbeda ketentuan hukumnya dan/atau akibat

Jilid III, h. 97.

${ }^{49}$ Ibn al-Qayyim, I'lâm al-Muwaqqi'în, Jilid III, h. 238.

${ }^{50}$ Abû Barakat Ahmad al-Dardîr, Al-Syarh al-Kabîr 'alâ al-Maqna', Jilid XII, (Bayrût: Dâr al-Fikr, t.th.), h. 132; Abû Zakariyâ Yahyâ Ibn Syaraf al-Nawawî, Raudhah al-Thâlibîn, Jilid III, (Bayrût: Dâr alKutub, 1412 H), Cet. I, h. 398.

${ }^{51}$ Ibn Qudâmah, Al-Mughnî, j. 6, h.436, Ibn Taimiyah, Majmû' Fatâwa Ibn Taimiyyah, j. 29, h.334. 
hukumnya saling berlawanan atau bertolak belakang. Larangan ini didasari atas larangan Nabi menggabungkan akad salaf dan jual beli. Dua akad ini mengandung hukum yang berbeda. Jual beli adalah kegiatan muamalah yang kental dengan nuansa dan upaya perhitungan untung-rugi, sedangkan salaf adalah kegiatan sosial yang mengedepankan aspek persaudaraan dan kasih sayang serta tujuan mulia. Karena itu, ulama Mâlikiyyah melarang multiakad dari akadakad yang berbeda hukumnya, seperti antara jual beli dengan ju'âlah, sharf, musâqah, syirkah, qirâdh, atau nikah. ${ }^{52}$

Meski demikian, sebagian ulama Mâlikiyyah dan mayoritas ulama nonMâlikiyyah membolehkan multiakad jenis ini. Mereka beralasan perbedaan hukum dua akad tidak menyebabkan hilangnya keabsahan akad. ${ }^{53}$ Dari dua pendapat ini, pendapat yang membolehkan multiakad jenis ini adalah pendapat yang unggul.

Larangan multiakad ini karena penghimpunan dua akad yang berbeda dalam syarat dan hukum menyebabkan tidak sinkronnya kewajiban dan hasil. Hal ini terjadi karena dua akad untuk satu objek dan satu waktu, sementara hukumnya berbeda. Sebagai contoh tergabungnya antara akad menghibahkan sesuatu dan menjualnya. Akad-akad yang berlawanan (mutadhâdah) inilah yang dilarang dihimpun dalam satu transaksi.

\section{Penutup}

Keharaman multiakad pada dasarnya disebabkan oleh tiga hal. Pertama, dilarang agama atau hîlah karena dapat menimbulkan ketidakpastian (gharar) dan ketidakjelasan (jahâlah). Kedua, menjerumuskan ke praktik riba. Ketiga, multiakad yang menimbulkan akibat hukum yang bertentangan pada objek yang sama. Dengan kata lain, multiakad yang memenuhi prinsip syariah adalah multiakad yang memenuhi standar atau dhawâbith, sebagaimana yang telah dikemukakan. []

\section{Pustaka Acuan}

'Imrânî, al-, 'Abd Allâh Ibn Muhammad bin 'Abd Allâh, Al-'uqûd al-Mâliyah alMurakkabah: Dirâsah Fiqhiyyah Ta'shîliyyah wa Tathbîqiyyah, Riyâdh: Dâr Kunûz Eshbelia li al-Nasyr wa al-Tauzî’, 2006.

Abâdi, al-, al-Fairûz, Al-Qâmûs al-Muhîth.

Al-Qarrâfî, Syarh Tanqîh al-Fushûl.

${ }^{52}$ Al-'Imrânî, Al-'uqûd al-Mâliyah al-Murakkabah, h.181-182.

${ }^{53}$ Ibn Juzayy, al-Qawânîn al-Fiqhiyyah, Tahqîq: 'Abd Allâh al-Minsyawi, (Al-Qâhirah: Dâr alHadîts, 2005), h.209-210 Al-'Imrânî, Al-'uqûd al-Mâliyah al-Murakkabah, h.126. 
Anas, Imâm Mâlik ibn, Al-Mudawwanah al-Kubrâ, Bayrût: Dâr al-Shâdir, 1323 H. , Al-Muwaththa'.

Ashfahânî, al-, Mu’jam Mufradât Alfâzh al-Qur'ân.

Bahuti, al-, Mansur Ibn Yûnus Ibn Idrîs, Kasyâf al-Qanâ' 'an Matn al-Iqnâ', Bayrû: Dâr al-Fikr, 1402 H.

Dardîr, al-, Abû Barakat Anhmad, Al-Syarh al-Kabîr 'alâ al-Maqna', Bayrût: Dâr alFikr, t.th.

Hammâd, Nazîh, Al-'uqûd al-Murakkabah fî al-Fiqh al-Islâmî, Damaskus: Dâr alQalam, 2005.

, Qadhâyâ Fiqhiyyah Mu'âshirah fi al-Mâl wa al-Iqtishâd, Damaskus: Dâr al-Qalam, 2001.

Hanbal, Imâm Abû 'Abd Allâh Aḥmad Ibn, Musnad Ahmad, Bayrût: Dâr al-Ihyâ alTurâts al-'Arabî, $1414 \mathrm{H}$.

Hazm, Abû Muhammad 'Ali Ibn Ahmmad Ibn Sa'îd bin, al-Muhallâ, j.5, Kairo: Dâr alTurâts, tt.

Ibn al-Qayyim, I'lâm al-Muwaqqi'în.

Ibn Juzayy, al-Qawânîn al-Fiqhiyyah, Tahqîq: 'Abd Allâh al-Minsyawi, Kairo: Dâr al-Hadîts, 2005.

Ibn Mandlûr, Lisân al-'Arab.

Ibn Qudâmah, Al-Mughnî.

-------------, Raudhah al-Nâdzir.

Ibn Rusyd, Bidâyah al-Mujtahid.

Ibn Taymiyyah, Al-Qawâ'id al-Nûrâniyyah al-Fiqhiyyah.

-----------, Jâmi' al-Rasâil.

-----------, Majmû' Fatâwa Ibn Taimiyyah.

, Nadzariyat al-'Aqd.

Imâm Bukhârî, Sahîh al-Bukhârî.

Imâm Muslim, Sahîh Muslim.

Jashâsh, al-, Abû Bakar Ahmad al-Râzî, Ahkâm al-Qur'an, j. 2, Bayrû: Dâr al-Fikr, tt.

Jauharî,. al-, Al-Shihâh.

Jauziyyah, al-, Ibn Qayyim, I'lâm al-Muwaqqi'în 'an Rab al-'Alamîn, Kairo:

Maktabah Ibn Taimiyyah, tt.

Jurjânî, al-, al-Ta'rîfât.

Kafawî, al-, al-Kulliyât.

Nawawî, al-, Abû Zakariyâ Yahyâ Ibn Syaraf, Raudhah al-Thâlibîn, Bayrût: Dâr alKutub, $1412 \mathrm{H}$.

Sa'ûd, al-, Ramadhân Muhammad Abû, Mabâdi al-Iltizâm fî al-Qânûn al-Mishri wa 
al-Banânia.

Syâfi'î, al-, Mukhtashar al-Muzanî, Bahâmis al-Umm.

Syâtibî, al-, Al-Muwâfaqât.

Tahânawî, al-, Kasysyâf Ishthilâhât al-Funûn, Bayrût: Dâr Shâdir, t.th.

Tim Penyusun, Kamus Besar Bahasa Indonesia, Jakarta: Balai Pustaka, 1996.

Utsmân, Mahmûd Hâmid, Al-Qâmûs al-Mubîn fî Ishthilâhât al-Ushûliyyîn, Riyâdh:

Dâr al-Zâhim, 1423 H. 